\title{
First report of Colletotrichum truncatum causing leaf anthracnose on Jatropha curcas in India
}

\author{
Arghya Banerjee $^{1}$ (D) Uday Bikash Oraon $^{1} \cdot$ Partha Sarathi Nath $^{1}$ \\ Received: 24 March 2020 / Accepted: 27 August 2020 / Published online: 31 August 2020 \\ (C) Società Italiana di Patologia Vegetale (S.I.Pa.V.) 2020
}

Keywords Biofuel crop $\cdot$ Leaf anthracnose $\cdot$ Pathogenicity confirmation $\cdot$ Molecular characterization $\cdot$ India

Jatropha curcas L. (Euphorbiaceae), commonly known as physic nut, is one of the important biodiesel crops of India. In July, 2018, symptoms of foliar necrosis were observed in six different fields of Jatropha curcas located at Kalyani, West Bengal, India. Disease incidence was 20-25\%. The most commonly observed symptoms were brown necrotic irregular lesions mostly appeared on the edges and center of the leaf which may contain a yellow halo. Necrotic tissues were embedded with minute brown setaceous acervuli which were detected through stereo-binocular microscopy. Isolation from diseased leaf samples yielded whitish to pale brown dense cottony mycelia mat on peptone salt agar (PSA) plates. Conidia were hyaline, aseptate, falcate, and $21.8_{-}^{-}$ $28.5 \times 2.6-3.4 \mu \mathrm{m}(n=50)$ in diameter. Based on morphology and cultural characteristics, the fungus was initially identified as Colletotrichum truncatum. The ITS, $\beta$-tubulin 2 (TUB2) and actin (ACT) regions of rDNA of a representative isolate (Ccb5) were amplified using the primers ITS1/ITS4 and T1/ Bt2b, ACT512F/ACT783R respectively and sequenced (GenBank accession No. ITS: MK211201, TUB2: MK217784, and ACT: MN255823). BLAST analyses showed $100 \%$ sequence identity with $C$. truncatum accessions in NCBI database (HM450126, JQ436737, KT375068, MT090051). Five isolates were evaluated for their pathogenicity on five $J$. curcas plants by spraying the leaves with a conidial suspension $\left(1 \times 10^{6}\right.$ conidia $\left./ \mathrm{ml}\right)$. Lesions typical of C. truncatum infection were observed in all five plants 10 days post inoculation. No symptoms were observed on noninoculated plants. Koch's postulates were confirmed by re-

Arghya Banerjee

arghyabanerjee18@gmail.com

1 Department of Plant Pathology, Bidhan Chandra Krishi Viswavidyalaya, Mohanpur, Nadia, West Bengal 741252, India isolation of the fungus from inoculated plants. C. truncatum has been reported from Mexico (Torres-Calzada et al. 2011) and Burkina Faso (Ellison et al. 2014) on Jatropha. According to the USDA host database, C. trancatum has also been reported as $C$. capsici from two other species of Jatropha in India, J. glandulifera and J. gossypifolia. As per our knowledge, this is the first report of $C$. truncatum causing leaf anthracnose on J. curcas in India (Farr and Rossman 2020).

\section{Compliance with ethical standards}

Conflict of interest All authors declare that they have no conflict of interest.

Research involving human participants and/or animals The authors declare that no human participants and animals were involved in this study.

Informed consent This manuscript is new and not being considered elsewhere. All authors have approved the submission of this manuscript.

\section{References}

Ellison CA, Sawadogo A, Braman S, Nacro S (2014) First report of Colletotrichum truncatum causing stem cankers on Jatropha curcas in Burkina Faso. Plant Dis 99(1):14-20. https://doi.org/10.1094/ PDIS-02-14-0181-RE

Farr DF, Rossman AY (2020) Fungal databases, U.S. National Fungus Collections, ARS, USDA. https://nt.ars-grin.gov/fungaldatabases/ fungushost/FungusHost.cfm. Accessed 9 Feb 2020

Torres-Calzada C, Tapia-Tussell R, Nexticapan-Garcez A, Matin-Mex R, Quijano-Ramayo A, Cortés-Velázquez A, Higuera-Ciapara I, PerezBrito D (2011) First report of Colletotrichum capsici causing anthracnose in Jatropha curcas in Yucatan, Mexico. New Dis Rep 23: 6. https://doi.org/10.5197/j.2044-0588.2011.023.006

Publisher's note Springer Nature remains neutral with regard to jurisdictional claims in published maps and institutional affiliations. 